\title{
Technical and Perceived Usability Issues in Arabic Educational Websites
}

\author{
Mohamed Benaida, Abdallah Namoun \\ Faculty of Computer and Information Systems \\ Islamic University of Madinah \\ Medina, Saudi Arabia
}

\begin{abstract}
Educational websites are often used as effective communication mediums to provide useful information for students and course instructors. The current study explores the perceived usability of three top-ranked Arabic educational websites across seven key usability components: effectiveness, efficiency, learnability, memorability, errors, satisfaction, and content. Moreover, the study also identifies the key technical and usability issues that currently exist within Arabic educational websites. A two-phase process encompassing automated tools and user testing was adopted to evaluate the technical performance and student acceptance of Arabic educational websites. In the automatic evaluation, two tools, namely, Web Page Analyser and GTMetrix, assessed the websites against a number of well-known performance guidelines and criteria. The student evaluation entailed 150 students completing three interaction tasks and evaluating the sites using the CSUQ questionnaire. The findings indicate that Arabic educational websites suffered from various technical issues, such as a high number of HTML objects and their large size and, consequently, slow loading speed. Moreover, the websites failed to satisfy all usability components, and students rated them negatively. Relevant guidelines for the effective design of Arabic educational websites are also discussed in this paper.
\end{abstract}

Keywords-Arabic educational websites; perceived usability; automatic evaluation; student perception

\section{INTRODUCTION}

Three major North African countries include Libya, Algeria, and Morocco. The majority of these countries' residents are young people, and the number of Internet users in these North African countries has risen dramatically from 300,000 in year 2000 to $47,721,000$ users in the year 2017 [44].

Internet users in general and students in North Africa in particular face many barriers in gaining high-speed Internet access. The main problems that discourage students, for example in Algeria, is a slow internet speed due to the limited reach of AT's fixed-line network and the inflation in the cost of Internet usage. In addition, the third generation (3G) connectivity has been in operation only recently, starting in December 2013 [1].

Research efforts investigating the design of Arabic websites are still few and so are the design guidelines for creating effective Arabic websites. However, in 2017 there were more than 185 million Arab users connected to the Internet, and Arabic is the third-used language on the Internet after English and Chinese [44]. This necessitates the need to carry out research studies exploring the usability and design of Arabic websites.

This research makes three distinct contributions. Firstly, it adds to the existing body of knowledge related to the usability of Arabic web user interfaces, which is still undeveloped. Secondly, it gauges students' overall perception of the current usability of Arabic educational websites and identifies the core technical and usability challenges from which these websites suffer. Thirdly, it proposes tentative recommendations to guide the effective design of Arabic educational websites.

The websites of three prominent universities in North Africa are examined in this paper, including Technology Houari Boumediene (USTHB) from Algeria, the University of Mohammed Premier in Oujda from Morocco, and the University of Benghazi from Libya. The remainder of this paper is divided into five sections. Section II reviews related studies, Section III reports on the experimental procedures and instruments, Section IV summarizes the main results, and Section $\mathrm{V}$ discusses the implications of the findings in respect to the design of Arabic websites.

\section{RELATED WORK}

\section{A. Usability and Usability Components}

Website usability has become more important than ever before to the success of a web design. Moreover, enabling users to find what they are looking for effortlessly and rapidly is considered to be a key ingredient in websites' success. Historically, the term 'usability' replaced the term 'userfriendly' in the 1980s [2]. Essentially, usability can be defined as the ease of use and acceptability of a system for a particular category of users carrying out specific tasks [3]. Usability, therefore, is concerned with achieving a specific goal and reducing the frustration that occurs when a situation hinders or stops someone from reaching their goal [4]. Research studies have demonstrated that various design factors, such as images, content, color, and logos, may directly influence users' satisfaction [5]-[7]. Indeed, the main usability components, including efficiency, effectiveness, learnability, and satisfaction, are intertwined [8].

Numerous studies have examined the usability of websites in different application areas, such as education, banking, healthcare, and mobile settings [8]-[12], [5]. Sometimes, websites fail to retain their users as a result of poor application of usability principles, which could be an indicator of poor knowledge and use of web design theories [14]. For instance, 
Juristo, Moreno, and Sanchez-Segura [13] emphasized that web designers should possess sufficient knowledge about psychology, ergonomics, and linguistics theories and principles that constitute the cornerstone of effective website creation [13]. Masood and Thigambaram [20] confirmed this finding in their observation of how children, aged 4-5 years, are effected by the usability of mobile applications. Their data analysis, collected through eye tracking technology, showed that there is a mental model gap between website designers and preschoolers, and they advised developers to adopt a usercentered design methodology when creating educational applications.

\section{B. Evaluation of Educational Websites}

There exists various usability methods to evaluate educational websites, including questionnaires, usability inspection, heuristic evaluation, field study, analysis of site usage logs, formal usability testing, and focus groups [5]. Tan et al. [25] compared the effectiveness of heuristic analysis and user testing during the evaluation of four commercial websites. Their results revealed that those two methods complement each other, as they tackle different usability problems. Heuristic analysis is generally associated with the initial stage of the design process whilst user testing is related to the latter stages of process design. However, [24] argued for the need to create a compound index to measure the perceived usability by combining major metrics such as task time, task completion rate, error rates, and satisfaction ratings.

In [22], the authors employed Shackel's usability model to develop a survey to measure the usability experience of finalyear students on e-learning websites. Indeed, prior experience was shown not to have any influence on the overall perceived usability. Instead, other usability attributes such as effectiveness, learnability, flexibility, and attitude were considered critical for achieving a pleasurable experience with e-learning webpages. Likewise, [26] analyzed the usability of Namık Kemal University's (NKU) website and found that four factors, namely attractiveness, helpfulness, efficiency, and learnability, are positively correlated with website usability and overall user perceptions. Both gender and web experience had moderating effects on users' usability perceptions. However, Kiget [18] performed a case study to assess various factors, including learnability, user-friendliness, culture, technological infrastructure, gender, and policy, that may drive the usability of Kenyan e-learning websites. Only learnability was identified as a key contributor to the usability of e-learning systems.

Şengel [9] discussed the level of usability pertaining to a particular university website in Turkey. Results showed that the majority of the users found the website easy to use, and the website proved to be a very useful source of information related to the university. In contrast, Sengal and Oncu [19] showed that the content provided by the Uludag University website needed more attention and should be reviewed and updated regularly. Moreover, gender was found to influence the perceived usability of the website, with females holding a more positive view about the website. Furthermore, [23] conducted a statistical study to assess the perceived usability and accessibility levels of three educational websites. Task completion times was found to correlate with the overall level of the user's satisfaction. In [38], the researchers discussed the participation of students in e-learning systems by focusing on various engagement methods such as participation of students in forums, blogs, and wikis. The results showed that the forums and wikis were more beneficial to the students' learning process than were the blogs.

In [17], the researchers examined multilingual websites and argued that these websites must be designed in a way that satisfies all users at the local and international levels. The authors proposed a framework and set of guidelines, including use of appropriate color and layouts, to be followed while designing Arabic-English websites. Moreover, [21] emphasized the need for designers to consider the cultural context when creating multi-lingual websites. In the context of our research, timid work efforts, such as [15], [16], [33], have been conducted in respect to establishing design recommendations and models serving the design of Arabic websites.

\section{EXPERIMENTAL SETUP}

\section{A. Selected University Websites}

In this study, the top ranked university in the year 2018 in three North African countries was considered, namely, Algeria, Morocco and Libya, for this experiment. This selection relied on Webometrics ranking [45], which is carried out by an independent research group in Europe that specializes in the analysis of web presence of universities.

Webometrics scores university websites on four weighted key indicators mainly, web presence (5\%), visibility $(50 \%)$, openness (10\%) and excellence (35\%) [46].

Web presence refers to the number of pages and rich files. Visibility refers to the number of backlinks from external networks to the university website. Transparency refers to the number of citations about the university in Google Scholar. Excellence refers to the number of top $10 \%$ research papers cited in Scimago Journals within the last 5 years.

TABLE. I. WEB RANKING OF SELECTED UNIVERSITY WEBSITES ACCORDING TO WEBOMETRICS

\begin{tabular}{|l|c|c|c|}
\hline $\begin{array}{l}\text { Name of } \\
\text { University } \\
\text { (Country) }\end{array}$ & $\begin{array}{l}\text { University of } \\
\text { Sciences and } \\
\text { Technology } \\
\text { Houari } \\
\text { Boumedien } \\
\text { (USTHB - } \\
\text { Algeria) }\end{array}$ & $\begin{array}{l}\text { Mohamed } \\
\text { Premier } \\
\text { University } \\
\text { Oujda (MPUO - } \\
\text { Morocco) }\end{array}$ & $\begin{array}{l}\text { Oniversity } \\
\text { of } \\
\text { ( UB - } \\
\text { Libya) }\end{array}$ \\
\hline $\begin{array}{l}\text { World } \\
\text { Rank }\end{array}$ & 2250 & 2345 & 4030 \\
\hline Arab Rank & 37 & 47 & 134 \\
\hline $\begin{array}{l}\text { Country } \\
\text { Rank }\end{array}$ & 1 & 2 & 9105 \\
\hline $\begin{array}{l}\text { Indicator } \\
\text { one: }\end{array}$ & 1522 & 10703 & 12072 \\
\hline $\begin{array}{l}\text { Indicator } \\
\text { two: }\end{array}$ & 6448 & 2385 & 3168 \\
\hline $\begin{array}{l}\text { Indicator } \\
\text { three: }\end{array}$ & 2414 & 1106 & 1270 \\
\hline $\begin{array}{l}\text { Indicator } \\
\text { four: }\end{array}$ & 1783 & & \\
\hline
\end{tabular}


The results of Webometrics analysis, as depicted in Table I, showed disparate ranking of the three websites in the Arab world, with the University of Sciences and Technology Houari Boumediene (USTHB) Website placed first (Fig. 1), followed by Mohamed Premier University Oujda (MPUO) Website (Fig. 2), and finally University of Benghazi (UB) Website (Fig. 3).

Table II compares the three websites across a range of design features and media elements including background color, languages used, font type and size used, and menus. Generally, all websites employ black, white and green text on a whitish background.

TABLE. II. The Main Design Features of University Websites, Key CROSS-DIFFERENCES ARE HIGHLIGHTED IN GGEY

\begin{tabular}{|c|c|c|c|}
\hline & $\begin{array}{l}\text { University of } \\
\text { Sciences and } \\
\text { Technology } \\
\text { Houari } \\
\text { Boumedien }\end{array}$ & $\begin{array}{l}\text { Mohamed } \\
\text { Premier } \\
\text { University } \\
\text { Oujda }\end{array}$ & $\begin{array}{l}\text { University } \\
\text { of } \\
\text { Benghazi }\end{array}$ \\
\hline & $\begin{array}{l}\text { (USTHB } \\
\text { Website) } \\
\end{array}$ & $\begin{array}{l}\text { (UMPO } \\
\text { Website) } \\
\end{array}$ & $\begin{array}{l}\text { (UB } \\
\text { Website) }\end{array}$ \\
\hline $\begin{array}{l}\text { Web } \\
\text { Ranking } \\
\text { using } \\
\text { Webometrics } \\
\text { in the Arab } \\
\text { World }\end{array}$ & 37 & 47 & 134 \\
\hline $\begin{array}{l}\text { Background } \\
\text { colour }\end{array}$ & $\begin{array}{l}\text { White and } \\
\text { light green }\end{array}$ & $\begin{array}{l}\text { White and light } \\
\text { grey }\end{array}$ & $\begin{array}{l}\text { White and } \\
\text { light grey }\end{array}$ \\
\hline $\begin{array}{l}\text { Languages } \\
\text { available }\end{array}$ & $\begin{array}{l}\text { Arabic, } \\
\text { English, } \\
\text { French }\end{array}$ & $\begin{array}{l}\text { Arabic, } \\
\text { English, } \\
\text { French, } \\
\text { Amazigh }\end{array}$ & $\begin{array}{l}\text { Arabic, } \\
\text { English }\end{array}$ \\
\hline $\begin{array}{l}\text { Search } \\
\text { engine }\end{array}$ & Not available & Top right & Top left \\
\hline $\begin{array}{l}\text { Text colours } \\
\text { used }\end{array}$ & $\begin{array}{l}\text { White, Black, } \\
\text { Green }\end{array}$ & White, Black & $\begin{array}{l}\text { White, } \\
\text { Black and } \\
\text { Grey }\end{array}$ \\
\hline $\begin{array}{l}\text { Font type } \\
\text { and size } \\
\text { (Title) }\end{array}$ & Arial, $21 \mathrm{PX}$ & $\begin{array}{l}\text { Titillium Web, } \\
\text { 23PX }\end{array}$ & $\begin{array}{l}\text { GE SS } \\
\text { TWO, 48 } \\
\text { PX Bold }\end{array}$ \\
\hline $\begin{array}{l}\text { Font type } \\
\text { and size } \\
\text { (Text) }\end{array}$ & Arial, 12 PX & $\begin{array}{l}\text { Titillium Web, } \\
\text { 13PX }\end{array}$ & $\begin{array}{l}\text { GE SS } \\
\text { TWO, } 12 \\
\text { PX Bold }\end{array}$ \\
\hline Menus & $\begin{array}{l}\text { One at the top } \\
\text { and another } \\
\text { on the right }\end{array}$ & Two at the top & $\begin{array}{l}\text { One at the } \\
\text { top }\end{array}$ \\
\hline $\begin{array}{l}\text { Pictures on } \\
\text { the home } \\
\text { page }\end{array}$ & $\begin{array}{l}2 \text { small } \\
\text { pictures }\end{array}$ & $\begin{array}{l}5 \text { big and } 25 \\
\text { small pictures }\end{array}$ & $\begin{array}{l}6 \text { big and } \\
11 \text { small } \\
\text { pictures }\end{array}$ \\
\hline Logo & Top left & Top right & Top Middle \\
\hline $\begin{array}{l}\text { Languages } \\
\text { mixed on } \\
\text { same page }\end{array}$ & No & $\begin{array}{l}\text { Yes (Arabic } \\
\text { and French } \\
\text { mixed) }\end{array}$ & No \\
\hline Layout & $\begin{array}{l}\text { Traditional, } \\
\text { three column } \\
\text { structure }\end{array}$ & $\begin{array}{l}\text { Traditional, } \\
\text { grid design }\end{array}$ & $\begin{array}{l}\text { Traditional, } \\
\text { two column } \\
\text { structure }\end{array}$ \\
\hline $\begin{array}{l}\text { Social } \\
\text { network } \\
\text { links }\end{array}$ & Not available & $\begin{array}{l}\text { Facebook, } \\
\text { Twitter, } \\
\text { YouTube }\end{array}$ & $\begin{array}{l}\text { Facebook, } \\
\text { Twitter, } \\
\text { YouTube, } \\
\text { Instagram }\end{array}$ \\
\hline \multirow[t]{2}{*}{$\begin{array}{l}\text { Animated } \\
\text { pictures }\end{array}$} & Not available & Top of & Top of \\
\hline & & the page & the page \\
\hline
\end{tabular}

The text font employed on the websites varies between Arial 12, Titillium Web 13, and GE SS TWO 12. Each website offers its content in at least two languages, Arabic and English. Remarkably, the UMPO website mix two languages, particularly Arabic with French, on the same page. Moreover, all websites use images on their home pages and provide a search engine for searching the content, apart from USTHB website. All three websites organize their content and media features within a column or grid-structured design. In respect to social exposure, the UMPO and UB websites enable their students to connect to social networking sites from their pages.

The following screenshots represent the home page of the three educational websites examined in this research study.

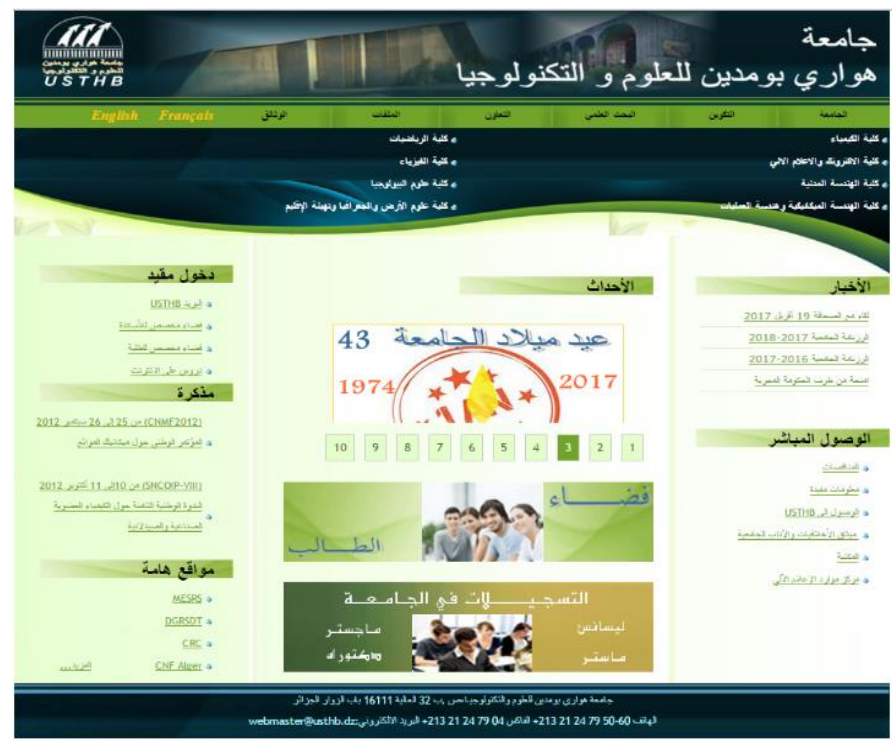

Fig. 1. Website One: University of Sciences and Technology Houari Boumedien Website [47].

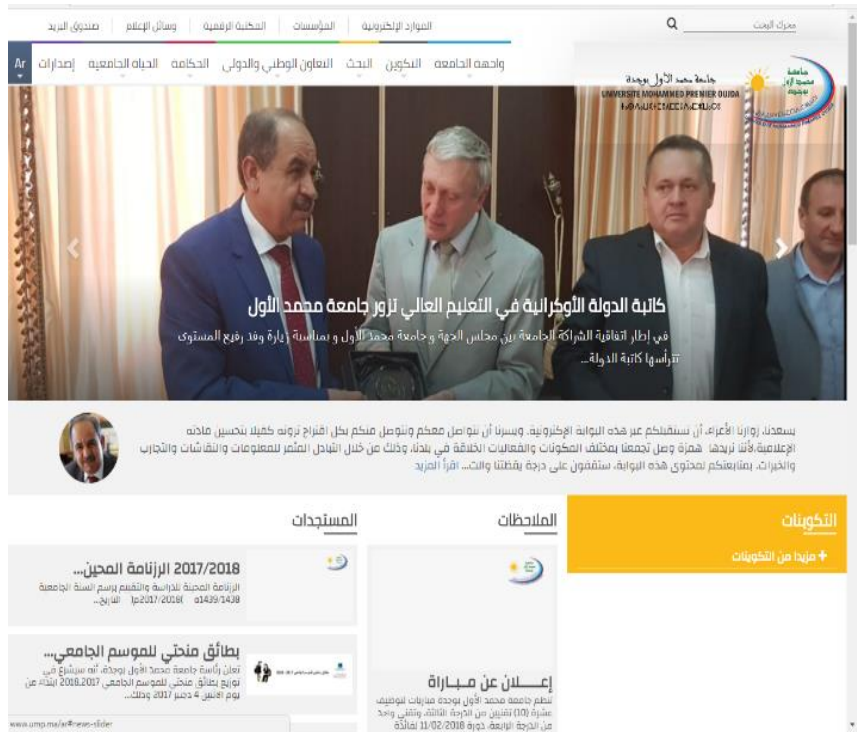

Fig. 2. Website Two: Mohamed Premier University Oujda Website [48]. 


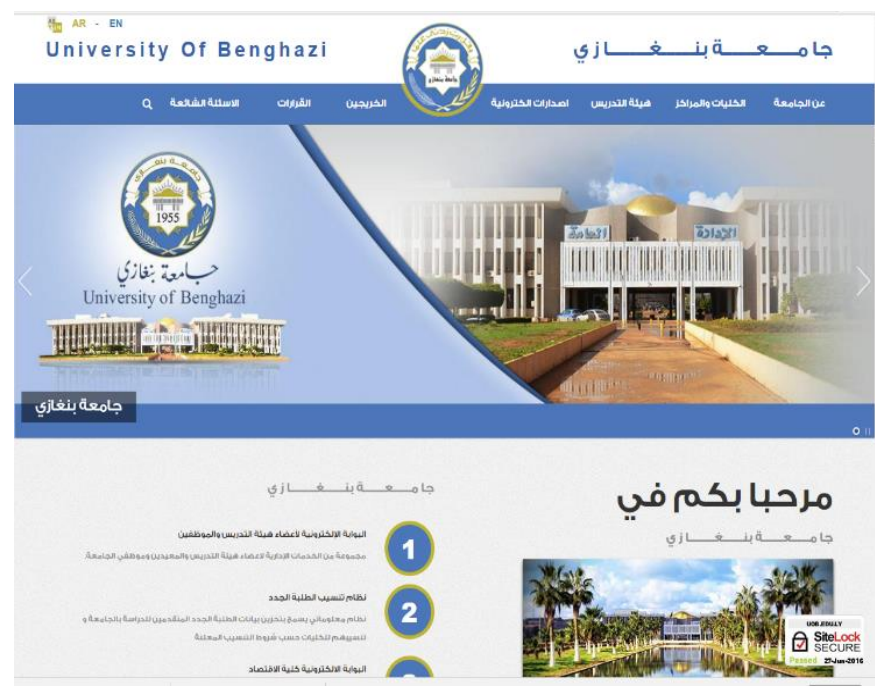

Fig. 3. Website Three: University of Benghazi website [49].

\section{B. Research Methodology}

This research employed a two-step evaluation procedure consisting of two differing yet complimentary approaches, a technical performance evaluation and user testing as depicted in Fig. 4. The technical assessment employs freemium website performance tools to check compliance with web technical guidelines and best practices that focus on optimizing various page aspects such as the page size, items number, and load time. Previous research showed that browsing frustration is strongly affected by slow downloads and connection drops [27]. However, the subjective evaluation engages actual students into the evaluation process and considers their opinions and feelings about the perceived usability of educational websites. Overall, this procedure empowers the creation of highly dedicated research recommendations for designing effective Arabic educational websites.

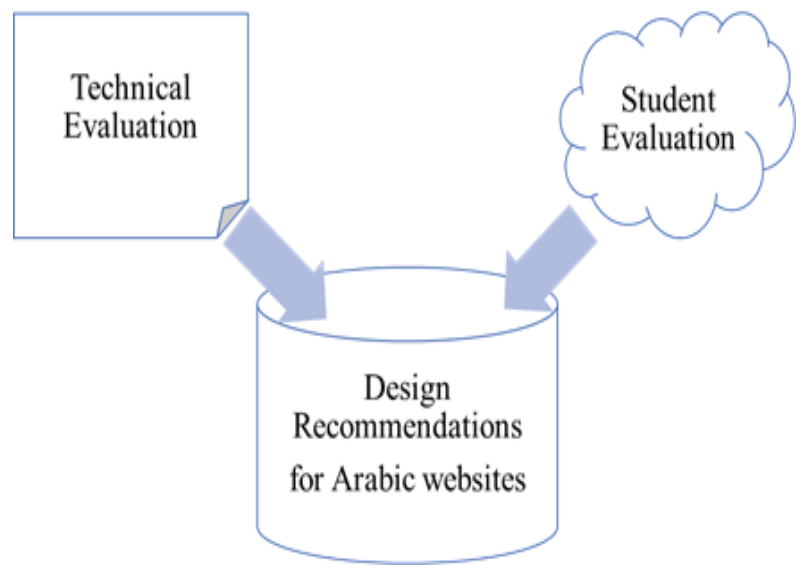

Fig. 4. Evaluation procedure of university websites.

\section{Automated Technical Evaluation}

The technical evaluation aims to assess web pages' performance by investigating a number of characteristics such as load speed of websites, size of pages and build-in features such as, number of objects and size of these objects. To this end, two automated evaluation tools were used to analyse the performance of our three educational websites. These tools are GTmetrix and Web Page Analyzer, respectively.

Two tables were produced using two website analysis tools, GTmetrix and Web Page Analyzer respectively. GTmetrix produced details about five main performance indicators namely PageSpeed Grade, YSow Grade, Fully loaded time, Total page size, and Total number of requests as listed in Table III. PageSpeed Grade is a measure from Google tools which indicates the degree of overall compliance to best practices, whereas Yahoo YSow grade is calculated using 23 rules, such as minimal use of DOM elements and small scale of images [50] believed to affect web page overall performance. Page speed scores from Google tools showed that none of the university websites surpass the average result from other websites (i.e. less than 71\%). Similarly, YSow results showed that only University of Benghazi website exceeded the average score from other websites (more than 69\%). When high Internet speed was used, all educational websites loaded fully in less than 6.7 seconds. However, in a more realistic scenario when low Internet speed was used, only the UB website fared quite well (4.9 seconds). Notably, UMPO webpage size totaled approximately $5.05 \mathrm{MB} \quad(2.86 \mathrm{MB}$ is the average recommendation) and has received substantially more HTTP requests (i.e. 108) during a month than the remaining websites.

TABLE. III. Web Pages Performance Results From GTMetrix [51], GRey Cells RePresent The ACCETABLe RESUlts Using CHROME (DESKOP) WITH HIGH INTERNET SPEED (MAIN 38.4 MBPS ) AND LOW INTERNET SPEED (MEAN=2.69 MBPS) [52]

\begin{tabular}{|l|l|l|l|l|}
\hline & $\begin{array}{l}\text { Average } \\
\text { Results } \\
\text { from Other } \\
\text { Websites }\end{array}$ & $\begin{array}{l}\text { USTHB } \\
\text { Website }\end{array}$ & $\begin{array}{l}\text { UMPO } \\
\text { Website }\end{array}$ & $\begin{array}{l}\text { UB } \\
\text { Website }\end{array}$ \\
\hline $\begin{array}{l}\text { PageSpeed } \\
\text { Grade } \\
\text { (Higher is } \\
\text { better) }\end{array}$ & $71 \%$ & $\mathrm{D}(54 \%)$ & $\mathrm{F}(23 \%)$ & $\mathrm{D}(63 \%)$ \\
\hline $\begin{array}{l}\text { YSow Grade } \\
\text { (Higher is } \\
\text { better) }\end{array}$ & $69 \%$ & $\mathrm{D}(61 \%)$ & $\mathrm{D}(60 \%)$ & $\mathrm{C}(75 \%)$ \\
\hline $\begin{array}{l}\text { Fully loaded } \\
\text { time (in } \\
\text { Second) using } \\
\text { high Internet } \\
\text { speed } \\
\text { (Lower is } \\
\text { better) }\end{array}$ & 6.7 & 4.4 & 4.9 & 3.7 \\
\hline $\begin{array}{l}\text { Fully loaded } \\
\text { time (in } \\
\text { Second) using } \\
\text { low Internet } \\
\text { speed } \\
\text { (Lower is } \\
\text { better) }\end{array}$ & 6.7 & 1.59 & 5.05 & 2.63 \\
\hline $\begin{array}{l}\text { Total page } \\
\text { size (MB) } \\
\text { (Lower is } \\
\text { better) }\end{array}$ & 2.86 & 8.7 & 6.0 & 4.9 \\
\hline $\begin{array}{l}\text { Total number } \\
\text { of requests } \\
\text { (Lower is } \\
\text { better) }\end{array}$ & 89 & 56 & 108 & \\
\hline
\end{tabular}


Although UB scored better than all websites, it received a high number of HTTP requests (103) which negatively influences the overall page loading time.

Table IV reports performance results from Web Page Analyzer [53] which given a URL of a website provides an objective performance analysis of the total number of objects, images, CSS, and scripts and size of HTML, images, CSS, and scripts on a web page. Overall results show that all three educational websites do not conform to most of the Web Page Analyzer guidelines with regards to the number and size of website items. However, only two criteria were adhered to namely HTML size and CSS size (except UMPO website). The evident issues, on the other hand, were the use of many objects, images, and scripts that exceed the recommended number and size for websites. Overall, UB website outperformed the other websites in respect to total and items' size, followed by USTHB website and finally UMPO website. This confirms the results of GTmetrix analysis.

Table. IV. Web Page Performance Results From Web Page ANALYSER (Numbers REPRESENT AVERAGE ON A Single PAGE), GREY CELls PReSENT The ACCEPTABLe Results [53].

\begin{tabular}{|c|c|c|c|c|}
\hline & $\begin{array}{l}\text { WPA } \\
\text { Guideline } \\
\text { (Should } \\
\text { be equal } \\
\text { to or less } \\
\text { than) }\end{array}$ & $\begin{array}{c}\text { (USTHB } \\
\text { Website) }\end{array}$ & $\begin{array}{c}\text { (UMPO } \\
\text { Website) }\end{array}$ & $\begin{array}{l}\text { (UB } \\
\text { Website } \\
\text { ) }\end{array}$ \\
\hline $\begin{array}{l}\text { Total } \\
\text { HTML files }\end{array}$ & 1 & 1 & 2 & 3 \\
\hline $\begin{array}{l}\text { Total } \\
\text { Objects }\end{array}$ & 20 & 84 & 55 & 66 \\
\hline $\begin{array}{l}\text { Total } \\
\text { Images }\end{array}$ & $\begin{array}{l}\text { reasonable } \\
\text { number }\end{array}$ & 65 & 35 & 53 \\
\hline Total CSS & 1 & 3 & 4 & 1 \\
\hline Total Script & 1 & 15 & 14 & 9 \\
\hline \multicolumn{2}{|l|}{ Total Items } & 168 & 110 & 132 \\
\hline $\begin{array}{l}\text { HTML Size } \\
\text { (bytes) }\end{array}$ & 50000 & 7205 & 25843 & 45862 \\
\hline $\begin{array}{l}\text { Image Size } \\
\text { (bytes) }\end{array}$ & 100000 & 1572344 & 1909354 & 694568 \\
\hline $\begin{array}{ll}\begin{array}{l}\text { Script } \\
\text { (bytes) }\end{array} & \text { Size } \\
\end{array}$ & 20000 & 154195 & 570609 & 542042 \\
\hline $\begin{array}{ll}\begin{array}{l}\text { CSS } \\
\text { (bytes) }\end{array} & \text { Size } \\
\end{array}$ & 8000 & 2807 & 10291 & 2478 \\
\hline $\begin{array}{l}\text { Total Size } \\
\text { (bytes) }\end{array}$ & 100000 & 1736551 & 2516097 & 1284950 \\
\hline
\end{tabular}

\section{Student Evaluation}

User testing refers to evaluating the educational websites with actual users, allowing to collect direct input and feedback from the respective students of these universities. In such kind of testing, the students are requested to carry out a set of realistic tasks and performance is measured using various usability metrics such as completion time, number of clicks and satisfaction scores.

\section{E. Perceived Usability Instrument}

Usability is defined by the international standard, ISO924111 as: 'the extent to which a product can be used by specified users to achieve specified goals with effectiveness, efficiency and satisfaction in a specified context of use'. Moreover, Nielsen [54] specified five important components that constitute usability: efficiency, learnability, memorability, errors, and satisfaction.

Accordingly, we have chosen to measure seven components believed to contribute to the perceived usability of educational websites. These components include effectiveness, efficiency, learnability, memorability, errors, satisfaction, and content. Below are their definitions.

- Effectiveness: refers to the rate of successfully completing tasks on the educational websites. This is also referred to as completion rate which is considered a critical performance metric.

- Efficiency: refers to the time taken, in seconds, to successfully complete designated tasks. Therefore, efficiency measures mainly the speed with which a certain task can be accomplished. It is referred to as task time.

- Learnability: refers to the efforts needed to learn to use the functionalities of the educational websites from the first time.

- Memorability: refers to the ability to recall how to use the educational websites on revisits after a period of discontinuity.

- Errors: refers to the number of mistakes or error rate when completing the intended tasks and actions.

- Satisfaction: refers to the liking of the system and pleasurable experience when using the educational websites. This is usually captured at the end of the test using a post study questionnaire.

- Content: refers to the quality and clearness of information, such as text, graphics or videos, provided on the educational websites.

Indeed, questionnaires have been used as a primary method to gather user views and satisfaction about web design [5]. In this study, we have opted to use the IBM Computer System Usability Questionnaire (CSUQ) to quantify the above usability components [28]. The CSUQ usability questionnaire has been shown to yield accurate results and requires only between 12 and 14 users to run [29]. Moreover, the CSUQ questionnaire is well known for its high reliability [28]. Overall, the CSUQ encompasses a total of 19 questions that need to be rated on a 7-point Liker scale. The students therefore had to rate the questions from $1=$ strongly disagree to $7=$ strongly agree. The rating scale included 'a not applicable' option as well. All questions of the CSUQ were translated to Arabic to enable the students to respond accurately in their first language.

We relied on the above definitions of the seven usability components in order to categorize the CSUQ questions as follows. 
TABLE. V. PERCEIVED USABILITY COMPONENTS AND RELEVANT ITEMS FROM CSUQ QUESTIONNAIRE

\begin{tabular}{|l|ll|}
\hline $\begin{array}{l}\text { Perceived } \\
\text { Usability } \\
\text { Component }\end{array}$ & Question Item \\
\hline Effectiveness & $\begin{array}{l}\text { - } \\
\text { It was simple to use this educational } \\
\text { website }\end{array}$ \\
I can effectively complete my work using \\
this educational website
\end{tabular}

\section{F. Procedure and Tasks}

The designated tasks and CQUS Arabic questionnaire were pilot tested with a total of 10 students from the three above universities to ensure smooth execution of the actual research study. However, no major concerns were raised by the participants. The research study was conducted during off peak times to ensure Internet highest speed.

After providing a short introduction about the study and its procedure, students were instructed to carry out the following activities:

- Read the study information sheet and sign a participation consent form.

- Fill out a short background information form about students' gender and experience using their university website.
- Explore freely the different sections of their university website for 5 minutes.

- Carry out three interactive search tasks using their university website.

- Upon completion of all tasks, evaluate seven usability components, listed in Table $\mathrm{V}$, of their university website using the CSUQ Arabic questionnaire.

The information search tasks completed by the students were varied in complexity and included three tasks. The direct URL link to the Arabic version of the university website was provided to the students.

- Task One: Find the year the University was established.

- Task Two: Find names of three research centers established in the University.

- Task Three: Find the different undergraduate degrees offered by the Faculty of Science.

These tasks were similar and were achievable through all three educational websites. These search tasks enabled the students to explore different sections and aspects of their university website. Two main usability metrics were recorded as the interaction unfolded. These metrics comprised of completion rate and task time.

\section{RESULTS}

In total 150 undergraduate students took part in this experiment, with 50 students coming from each university. The students were undertaking degrees from different faculties of their University. Overall, $51 \%$ of the students were male and $49 \%$ were female. Approximately $48 \%$ of the students reported using their university website on a regular basis (i.e. a few times a week or more) as shown in Fig. 5.

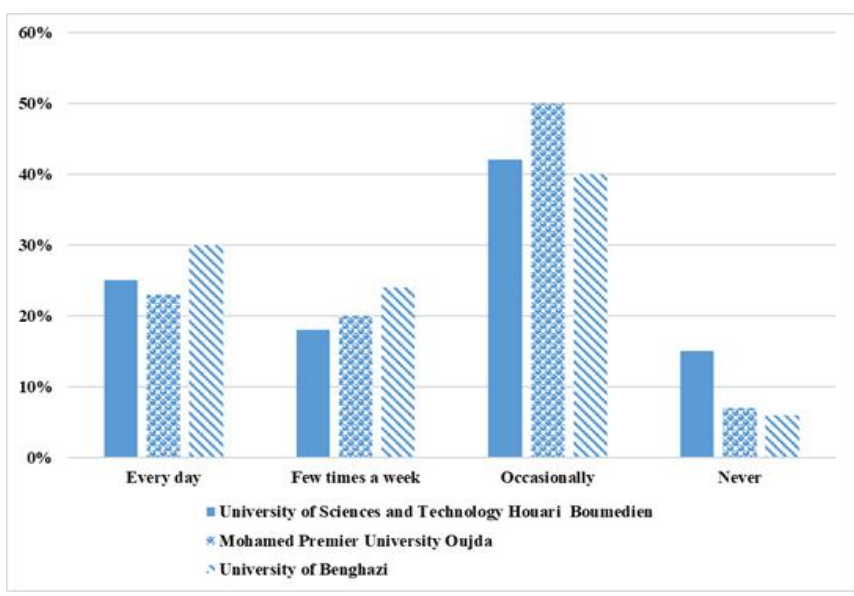

Fig. 5. Frequency of website use.

On average, the results indicated that the students spent the longest time to complete the third task (99.67 seconds) in comparison to the remaining tasks $(\mathrm{p}<.001)$, as shown in Fig. 6. Similarly, the third task was deemed as the most challenging and resulted in the lowest completion rate in the UMPO website. In the third task, the students were instructed to find the Bachelor programs offered by the Faculty of 
Science. In the UMPO website, these Bachelor programs were available in an external page (i.e. not belonging to the same domain of the Arabic version of the University website) and they were written in French which might have confused the students. Similarly, task one resulted in $62 \%$ completion rate in the UMPO website due to the unclear navigation structure employed within the website, as shown in Fig. 7.

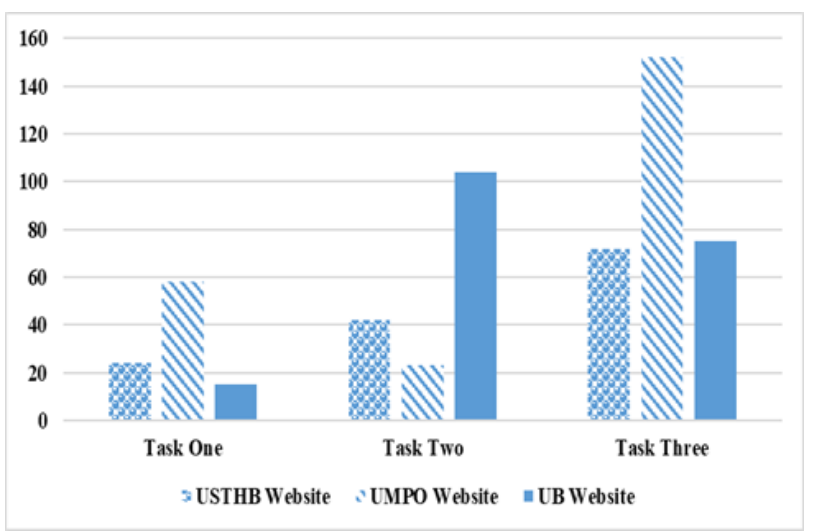

Fig. 6. Task time (seconds).

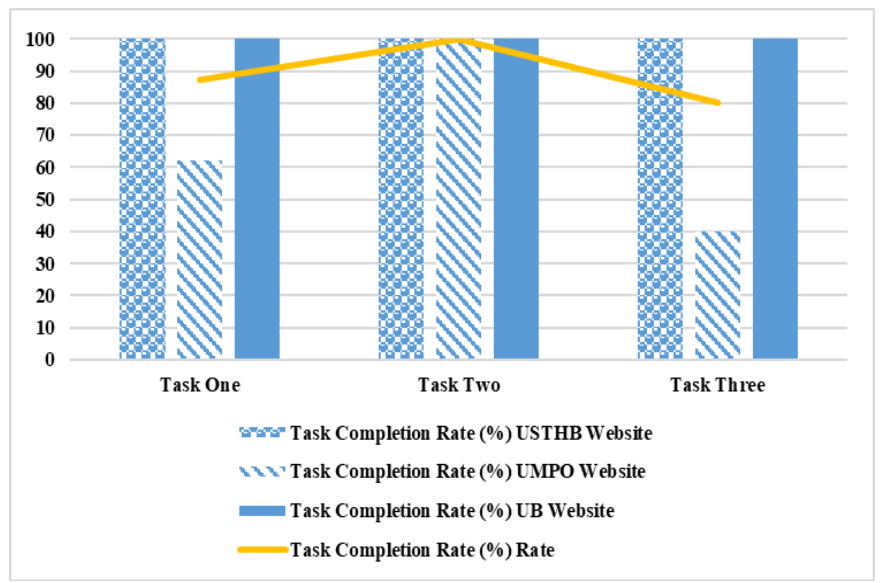

Fig. 7. Task completion rate (\%).

A contrast between the three educational websites using their average score of the two performance metrics reveals that UMPO website performed the worst as it took longer time to complete the tasks (77.66 seconds per task) and its students failed to complete all information search tasks (67.33\% average completion rate) $(\mathrm{p}<.001)$, as depicted in Fig. 8. However, the USTHB website outperformed the remaining websites as its students answered all questions correctly within an average speed of 46 seconds per task. This indicates that a good navigational structure is employed in the USTHB website. Finally, UB website trailer behind the USTHB website as it scored the same completion rate but its students took slightly longer to complete the search tasks (65 seconds per task).
Following the completion of search tasks, the students rated various aspects of the perceived usability of their university websites. Cronbach's alpha test showed good reliability of all usability components proposed in Table $\mathrm{V}(\alpha=0.86)$. All questions of the CSUQ were rated on a 7-point Likert scale. Table VI summarizes the results of the students' rating of the three educational websites. It shows that the average score of almost all usability components were scored below 4, the acceptable threshold, across the three websites. This indicates low perceived usability and satisfaction by the students towards their university websites.

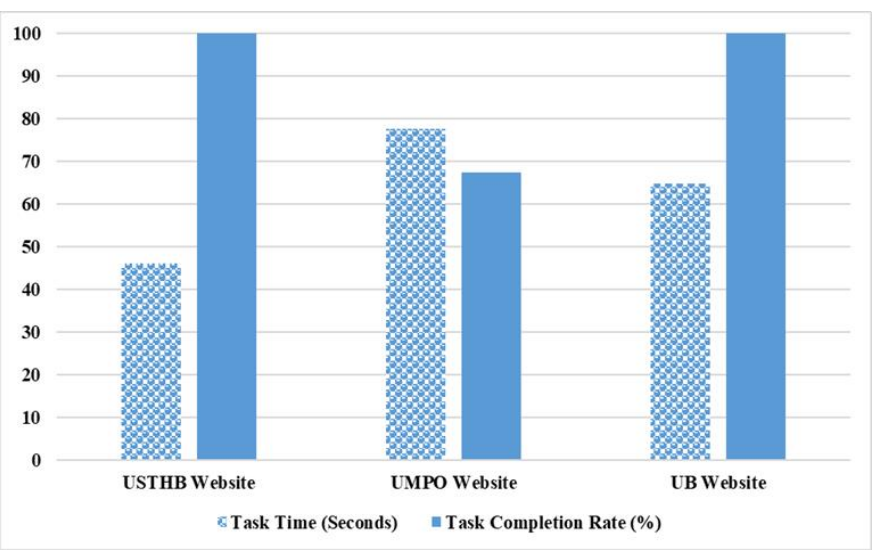

Fig. 8. Performance comparison across the educational websites.

Overall, UB website received a better evaluation than the other websites across most of the usability components ( $\mathrm{p}<.001$ ), except efficiency and satisfaction. On the other hand, UMPO website received the worst rating score in respect to four components mainly effectiveness, learnability, content, and errors. The effectiveness mean for all educational websites was 3.01, with UB website receiving the highest average and UMPO receiving the lowest average. This result agrees with the performance results. The efficiency mean did not differ across the three websites (average $=3.13$ ).

On average, the learnability component received the highest rating score (mean=3.75) across all educational websites, with the UB website as the favorite (mean=4.22). This component had the highest score amongst all other usability factors. However, the memorability mean for all websites was quite low (mean=2.52), with the UB website receiving the highest score and USBTH website receiving the lowest score. On average, the quality of content received the second best rating score (mean=3.15) among all components, with the UMPO website scoring the worst (mean=2.98). On the contrary, the websites were rated very poorly for providing error messages to help resolve problems (mean $=2.19)$, with the UMPO website perceived as the worst on this component. Finally, the students did not like the design of their educational websites and were general unsatisfied (mean=2.97). 
TABLE. VI. Students Rating of Perceived Usability Components of the Three EduCATional Websites (Light GREy RePRESENTS Worst Rating; DARK GREY REPRESENTS BEST RATING)

\begin{tabular}{|c|c|c|c|c|c|c|c|c|}
\hline \multirow{2}{*}{ Usability Component } & \multicolumn{2}{|c|}{ USBTH Website } & \multicolumn{2}{|c|}{ UMPO Website } & \multicolumn{2}{|c|}{ UB Website } & \multirow{2}{*}{$\begin{array}{l}\text { Mean } \\
\text { Score (all } \\
\text { websites) }\end{array}$} & \multirow{2}{*}{ Sig value } \\
\hline & Mean & STD & Mean & STD & Mean & STD & & \\
\hline Effectiveness & 2.88 & 0.82 & 2.63 & 0.62 & 3.51 & 0.76 & 3.01 & .000 \\
\hline Efficiency & 3.13 & 0.95 & 2.96 & 0.56 & 3.29 & 0.59 & 3.13 & NS \\
\hline Learnability & 3.76 & 1.49 & 3.26 & 1.01 & 4.22 & 1.25 & 3.75 & .000 \\
\hline Memorability & 2.1 & 1.34 & 2.5 & 0.94 & 2.96 & 1.03 & 2.52 & .001 \\
\hline Content / Information & 3.21 & 0.79 & 2.89 & 0.45 & 3.36 & 0.58 & 3.15 & .000 \\
\hline Errors & 2.1 & 1.04 & 1.8 & 0.77 & 2.68 & 1.3 & 2.19 & .001 \\
\hline Satisfaction & 2.97 & 1.02 & 2.99 & 0.96 & 2.95 & 0.82 & 2.97 & NS \\
\hline $\begin{array}{l}\text { Average perceived } \\
\text { usability score }\end{array}$ & 2.88 & & 2.72 & & 3.28 & & & \\
\hline
\end{tabular}

\section{DISCUSSION}

To the best of our knowledge, this research study is the first to examine the perceived usability of North African educational websites, with a focus on the top web ranked universities in Morocco, Algeria, and Libya. These websites used Arabic as the main language in addition to at least one secondary language. Typically, educational websites provide useful information for students and instructors and are used as a communication medium with these stakeholders [30]. It is therefore important to ensure high usability of these websites and the use of effective design elements to maximize educational gains. This will, in turn, help achieve the educational institution's goals.

Our study comprised two methods of evaluation, automatic evaluation and empirical evaluation, of the educational websites. Barnes et al. [31] showed that using data from multiple methods of testing yields better results and gives more insights about users' perceptions. In automatic evaluation, a tool checks for whether or not the educational websites adhere to web standards and best practices [32]. In empirical evaluation, actual students are recruited to complete search tasks and provide their views about the perceived usability of these websites [32]. The results of both evaluations indicated that our three Arabic educational websites failed to meet the performance and usability expectations of their students.

The web performance results from Web Page Analyzer and GTMetrix showed weak scores for all educational websites. The major technical problems involved the large size of images and JavaScript within the sites, lack of scaled images, absence of browser caching, the parsing of JavaScript during initial page load, the large number of objects, the lack of compression to optimize transfer size, and serving the same web resources from multiple URLs. These problems negatively impact the page load times. Even using high Internet speeds, page loading results were still below the recommendations. The page loading speed of all educational websites was less than 6.9 seconds. However, Kissmetrics has suggested that around $40 \%$ of site users will abandon the website if the loading time exceeds more than 3 seconds [43]. It is well-documented in the literature that a slow website increases user frustration, affects the overall judgment of the website, and discourage users from returning to the website [34].

The student evaluation encompassed the completion of three information search tasks and the rating of seven usability components, namely effectiveness, efficiency, learnability, memorability, errors, content, and satisfaction, which were derived from the CSUQ questionnaire. The overall rating showed weak usability perceptions by the students across all usability components. The UMPO website obtained the worst rating for its content, possibly as a result of mixing two languages on the same pages. Similarly, it received a poor rating for error handling and prevention, as students were often directed to the French version of the site and experienced difficulty returning back to the Arabic version. Students were also unable to complete all tasks on the UMPO website due to the poorly designed navigation menu. Previous research has emphasized the importance of content and navigation within educational websites for overall student preference of websites [35]. Further, Nielsen suggested paying particular attention to response time, content, and navigation mode [36], and Naidu [37] claimed that the terminology, length of pages, and organization of links affects the search performance. In our view, the poor performance results might have also influenced the perceived usability of the Arabic educational websites.

\section{CONCLUSION AND FUTURE WORK}

This paper proposes, based on the findings of our evaluation, design recommendations to guide the development of educational Arabic websites. These recommendations aim at enhancing the performance of web pages and improving the perceived usability of these pages for students.

\section{A. Website Performance Implications}

Top-ranked educational websites in three Arab countries were overburdened with the use of excessive web elements, including images, objects, and scripts. Both the number and size of these elements exceeded the existing recommendations. Optimization was absent, which led to weak performance and 
prolonged loading times in the educational websites. It is advised to minimize the number of website objects, which in turn reduces the number of HTTP requests. This will expedite the web response and loading time. Moreover, the size of website objects such as images should be maintained at minimum sizes to accommodate slow Internet connections. This design recommendation supports previous findings where users were found to be mainly frustrated by long download times [27]. Lazar et al. [39] confirmed that the time lost during the interaction increases student frustration levels.

\section{B. Perceived Usability Implications}

Students' ratings of seven usability components include effectiveness, efficiency, learnability, memorability, error, content, and satisfaction, revealed poor student experience. This student dissatisfaction could result in website abandonment. For instance, SC Chang and FC Tung [40] confirmed that perceived ease of use is major indicator of students' intention to use educational websites. In addition to including relevant and useful content, it is important to design educational websites that are easy to use. This agrees with the suggestions provided in [41].

The current study has initiated research into the perceived usability of Arabic educational websites and raised several concerns regarding the performance and satisfaction of students. Although our study provides initial recommendations, further research is encouraged to better understand the weak student satisfaction towards their Arabic educational websites. Quantitative results indicated some key findings, however these findings would need to be complemented by a qualitative investigation to derive conclusive guidelines and a deeper understanding of students' overall experiences. Moreover, the link between educational websites' performance and student satisfaction needs to be explored in future research. Previous research has shown that longer loading times correlate with user frustration, which could consequently affect overall acceptance and use of websites [27], [39]. Finally, aesthetics might have played a role in framing the perceived usability, as demonstrated in previous research studies [42].

\section{REFERENCES}

[1] S. Chaabna and H. Wang, "Analysis of the State of E-commerce in Algeria," International Journal of Marketing Studies, vol. 7, no. 2, 2015.

[2] N. Bevan, J. Kirakowski and J. Maissel, "What is usability?. Human Aspects in Computing Design and Use of Interacticve Systems and Work with Terminals," $4^{\text {th }}$ International Conference on Human Computer Interaction, 1991.

[3] A. Holzinger, "Usability engineering methods for software developers," Communications of the ACM, vol. 48, no. 1, pp. 71-74, 2005.

[4] V. Mendoza and D.G. Novick, "Usability over time," Proceedings of the $23^{\text {rd }}$ annual international conference on Design of communication: documenting and designing for pervasive information, ACM, pp. 151$158,2005$.

[5] V. Venkatesh, H. Hoehle and R. Aljafari, "A usability evaluation of the Obamacare website," Government information quarterly, vol. 31, no. 4, pp. 669-680, 2014.

[6] I.M. Hanafy and R. Sanad, "Colour preferences according to educational background," Procedia-Social and Behavioral Sciences, vol. 205, pp. 437-444, 2015.

[7] E.Ş. Ekici, C. Yener, N. Camgöz and E.Ahin, "Colour naming," Optics and Laser Technology vol. 38, no. 4-6, pp. 466-485, 2006.
[8] J. Jeng, "Usability Assessment of Academic Digital Libraries: Effectiveness, Efficiency, Satisfaction, and Learnability," Libri, vol. 55, pp. 96-121, 2005.

[9] E. Şengel, "Usability level of a university web site, " $4^{\text {th }}$ International Conference on New Horizons in Education, Procedia-Social and Behavioral Sciences, vol. 106, pp. 3246-3252, 2013.

[10] C. Buchmayer, M. Greil, A.L Hikl, O.Kaiser-Dolidze and C. Miniberger, "Usability on the Edge: The Implementation of u: cris at the University of Vienna," Procedia Computer Science, vol. 33, pp. 103109, 2014.

[11] C.A. Gumussoy, "Usability guideline for banking software design," Computers in Human Behavior, vol. 62, pp. 277-285, 2016.

[12] E. Çetin and S. Özdemir, "A Study on an Educational Website's Usability," Procedia-Social and Behavioral Sciences, vol. 83, pp. 683688, 2013.

[13] N. Juristo, A. M. Moreno and M. I Sanchez-Segura, "Analysing the impact of usability on software design," Journal of Systems and Software, vol. 80, no. 9, pp. 1506-1516, 2017.

[14] S. Qayyum and S. Rafiq, "Website Design Usability Issues Faced by the User in Pakistan," Computer Engineering and Intelligent Systems, vol.7, no.9, 2016

[15] L. Hasan, "Heuristic evaluation of three Jordanian university websites," Informatics in Education, vol. 12, no. 2, pp. 231-251, 2013.

[16] L. Hasan, "Evaluating the usability of educational websites based on students' preferences of design characteristics," International Arab Journal of e-Technology, vol. 3, no. 3, pp. 179-193, 2014.

[17] M. A. Ababtain and A. R. Khan, "Towards a Framework for Usability of Arabic-English Websites," Procedia Computer Science, vol. 109, pp. 1010-1015, 2017.

[18] N. K. Kiget, G. Wanyembi and A. I. Peters, "Evaluating usability of elearning systems in universities," International Journal of Advanced Computer Science and Applications, vol. 5, no. 8, pp. 97-102, 2014.

[19] E. Şengel, and S.Öncü, "Conducting preliminary steps to usability testing: investigating the website of Uludağ University," Procedia-Social and Behavioral Sciences, vol. 2, no. 2, pp. 890-894, 2010.

[20] M. Masood and M. Thigambaram, "The usability of mobile applications for pre-schoolers," Procedia-Social and Behavioral Sciences, vol. 197, pp. 1818-1826, 2015.

[21] M. Hillier, "The role of cultural context in multilingual website usability," Electronic Commerce Research and Applications, vol. 2, no. $1,2003$.

[22] M. H. Thowfeek and M. N. A. Salam, "Students' Assessment on the Usability of E-leaming Websites," Procedia-Social and Behavioral Sciences, vol. 141, pp. 916-922, 2014.

[23] S. Roy, P. K. Pattnaik and R. Mall, "A quantitative approach to evaluate usability of academic websites based on human perception," Egyptian Informatics Journal, vol. 15, no. 3, pp.159-167, 2104.

[24] G. J. Esmeria and R. R. Seva, "Web Usability: A Literature Review," Presented at the DLSU Research Congress 2017 De La Salle University, Manila, Philippines, 2017.

[25] W. S. Tan, D. Liu and R. Bishu, "Web evaluation: Heuristic evaluation vs. user testing, " International Journal of Industrial Ergonomics, vol. 39, no. 4, pp. 621-627, 2009.

[26] S. A. Mentes and A. H. Turan, "Assessing the usability of university websites: an empirical study on Namik Kemal University, " TOJET: The Turkish Online Journal of Educational Technology, vol. 11, no. 3, 2012.

[27] I. Ceaparu, J. Lazar, K. Bessiere, J. Robinson and B. Shneiderman, "Determining Causes and Severity of End-User Frustration," International Journal of Human-Computer Interaction, vol. 17, no. 3, pp. 333-356, 2004.

[28] R. J. Lewis, "IBM computer usability satisfaction questionnaires: Psychometric evaluation and instructions for use," International Journal of Human-Computer Interaction, vol. 7, no. 1, pp. 57-78, 1995.

[29] T. S. Tullis and J. N. Stetson, "A comparison of questionnaires for assessing website usability," Usability professional association conference, 2004. 
[30] H. Yu-chang, "Better educational website interface design: the implications from gender-specific preferences in graduate students," British Journal of Educational Technology, vol. 37, no. 2, pp. 233-242, 2006.

[31] S. J. Barnes and R. T. Vidgen, "Data triangulation and web quality metrics: A case study in e-government," Information \& Management, vol. 43, no. 6, pp. 767-777, 2006.

[32] P. Helen and N. Bevan, "The Evaluation of Accessibility, Usability, and User Experience," The Universal Access Handbook, C Stepanidis (ed), CRC Press, vol. 1, no. 16, 2009.

[33] L. Hasan, "The usefulness of user testing methods in identifying problems on university websites," JISTEM-Journal of Information Systems and Technology Management, vol. 11, no. 2, pp. 229-256, 2014.

[34] F. H. Nah, "A study on tolerable waiting time: how long are web users willing to wait," Behaviour \& Information Technology, vol. 23, no. 3, pp. 153-163, 2004.

[35] S. Ozkan and R. Koseler, "Multi-dimensional students' evaluation of elearning systems in the higher education context: An empirical investigation," Computers \& Education, vol. 53, no. 4, pp. 1285-1296, 2009.

[36] J. Nielsen, "Designing web usability, " Indianapolis, IN: New Riders Publishing, 1999.

[37] S. Naidu, "Evaluating the usability of educational websites for children," Usability News, vol. 7, no. 2, pp. 1-7, 2005.

[38] T. Miyazoe and T. Anderson, "Learning outcomes and students' perceptions of online writing: Simultaneous implementation of a forum, blog, and wiki in an EFL blended learning setting," System, vol. 38, no. 2, pp. 185-199, 2010.
[39] J. Lazar, A. Jones, M. Hackley and B. Shneiderman, "Severity and impact of computer user frustration: A comparison of student and workplace users," Interacting with Computers, vol. 18, no. 2, pp. 187207, 2005.

[40] S. C. Chang and F. C. Tung, "An empirical investigation of students' behavioural intentions to use the online learning course websites," British Journal of Educational Technology, vol. 39, no. 1, pp. 7183.2008.

[41] S. M. Almahamid, A. F. Tweiqat and M. S. Almanaseer, "University website quality characteristics and success: lecturers' perspective," International Journal of Business Information Systems, vol. 22, no. 1, pp. 41-61, 2016.

[42] A. Sonderegger and J. Sauer, "The influence of design aesthetics in usability testing: Effects on user performance and perceived usability," Applied ergonomics, vol. 41, no. 3, pp. 403-410, 2010.

[43] https://www.kissmetrics.com/

[44] http://www.internetworldstats.com/stats19.htm

[45] http://www.webometrics.info/en

[46] http://www.webometrics.info/en/node/200

[47] http://www.usthb.dz/ar/

[48] http://www.ump.ma/ar

[49] http://uob.edu.ly/

[50] http://yslow.org/

[51] https://gtmetrix.com/recommendations.html

[52] https://speedof.me/

[53] http://www.websiteoptimization.com/services/analyze/

[54] https://www.nngroup.com/articles/usability-101-introduction-tousability/ 